\title{
Evaluation of the health of energetic crops in Podkarpacie region
}

\section{Ocena zdrowotności roślin energetycznych w warunkach Podkarpacia}

\author{
Ewa Szpunar-Krok*, Ewa Stompor-Chrzan, Sabina Grochowska, Dorota Bobrecka-Jamro
}

\begin{abstract}
Summary
The field trials were conducted over the period 2012-2013 at Krasne near Rzeszów $\left(50^{\circ} 03^{\prime} \mathrm{N} ; 22^{\circ} 06^{\prime} \mathrm{E}\right)$. The occurrence of diseases caused by fungi on the aboveground parts of energy crops was investigated. In both years of the observations the following diseases were recorded: powdery mildew (Erysiphe cichoreacerum) on Helianthus tuberosus (leaves and shoots), gray mold (Botrytis cinerea) on Helianthus tuberosus and Sylphium perfoliatum (leaves), Sclerotinia sclerotiorum on Sida hermaphrodita (shoots). Leaf spots were observed on Miscanthus giganteus, Miscanthus sacchariflorus (Alternaria alternata, Helminthosporium spp., Stagonospora tainaenensis) and on Sida hermaphrodita (Phoma sp.). The highest mean intensity of powdery mildew was found on $H$. tuberosus (leaves), leaf spots on S. hermaphrodita (leaves) and sclerotinia rot on S. hermaphrodita (shoots). The intensity of diseases depended on weather conditions and plant species.
\end{abstract}

Key words: energy crops; severity; diseases

\section{Streszczenie}

W latach 2012-2013 badano występowanie chorób powodowanych przez grzyby na nadziemnych częściach roślin energetycznych uprawianych w Krasnem koło Rzeszowa $\left(50^{\circ} 03^{\prime} \mathrm{N} ; 22^{\circ} 06^{\prime} \mathrm{E}\right)$. W obu latach badań wystąpiły: mączniak prawdziwy (Erysiphe cichoreacerum) na roślinach Helianthus tuberosus (liście i pędy), szara pleśń (Botrytis cinerea) na Helianthus tuberosus i Sylphium perfoliatum (liście), zgnilizna twardzikowa (Sclerotinia sclerotiorum) na Sida hermaphrodita (pędy), a plamistość liści notowano na Miscanthus giganteus i Miscanthus sacchariflorus (Alternaria alternata, Helminthosporium spp., Stagonospora tainaenensis) oraz na Sida hermaphrodita (Phoma sp.). Stwierdzono największe średnie nasilenie mączniaka prawdziwego na $H$. tuberosus (liście), plamistości liści na S. hermaphrodita (liście) i zgnilizny twardzikowej na S. hermaphrodita (pędy). Intensywność nasilenia chorób zależała od warunków pogodowych i gatunku rośliny.

Słowa kluczowe: rośliny energetyczne; zdrowotność; choroby 


\section{Wstęp / Introduction}

W strategii Unii Europejskiej w zakresie energetyki coraz większy nacisk kładzie się na pozyskiwanie energii ze źródeł odnawialnych. Jednym $\mathrm{z}$ takich źródeł, najstarszych i powszechnych, jest biomasa, pochodząca z różnych upraw rolniczych, których rośliny wykazują w dość krótkim czasie duży przyrost, stosunkowo wysoką wartość opałową, odporność na choroby i szkodniki oraz mają małe wymagania glebowe.

W Polsce do roślin energetycznych polecanych na plantacje należą: Salix viminalis, Sida hermaphrodita, Helianthus tuberosus, Miscanthus giganteus i Miscanthus sacchariflorus. Wymienione rośliny mają zastosowanie nie tylko na cele energetyczne, ale w zależności od gatunku, są także wykorzystywane jako rośliny pastewne, przeciwerozyjne, rekultywacyjne, lecznicze, miododajne, kosmetyczne, kulinarne i w przemyśle drzewno-papierniczym. Również $\mathrm{z}$ uwagi na posiadane walory dekoracyjne (pokrój, faktura, kwiatostan) stanowią istotny element na obszarach krajobrazu otwartego.

O wysokiej jakości surowców roślin energetycznych decyduje ich zdrowotność. Z literatury wiadomo, że nadziemnym częściom roślin energetycznych zagraża wiele chorób występujących zarówno na liściach, jak i na pędach (Remlein-Starosta 2007, 2008a). W specjalistycznych kolekcjach roślin zakładanych w celach dydaktyczno-naukowych, celowe jest również dążenie do podniesienia ich zdrowotności, z uwagi na pozyskiwanie dobrej jakości materiału rozmnożeniowego, wysokiego plonu, a także estetycznego wyglądu roślin.

Celem badań było określenie nasilenia występowania chorób powodowanych przez grzyby na roślinach energetycznych, uprawianych w rejonie Podkarpacia.

\section{Materiały i metody / Materials and methods}

Materiał roślinny stanowiła specjalistyczna kolekcja roślin energetycznych, zlokalizowana na polu doświadczalnym Wydziału Biologiczno-Rolniczego Uniwersytetu Rzeszowskiego, w Krasnem koło Rzeszowa (5003’N, $\left.22^{\circ} 06^{\prime} E\right)$. Kolekcję założono w celach edukacyjnych i naukowych w 2007 r., na glebie średniej, podgrupy granulometrycznej pył gliniasty (pyg), klasy bonitacyjnej IIIa, kompleksu pszennego dobrego. Na poletkach o powierzchni $30 \mathrm{~m}^{2}$ uprawiano 5 gatunków roślin energetycznych: słonecznik bulwiasty (topinambur) (H. tuberosus), ślazowiec pensylwański (S. hermaphrodita), miskant olbrzymi (M. giganteus), miskant cukrowy (M. sacchariflorus) i sylfię przerośniętą (rożnik przerośnięty) (Sylphium perfoliatum). Rośliny wysadzono w rozstawie rzędów: 0,60 $\mathrm{m} \times 0,35 \mathrm{~m}$ (S. hermaphrodita, S. perfoliatum i $H$. tuberosus), $1 \mathrm{~m} \times 1 \mathrm{~m}$ (M. giganteus) oraz $1 \mathrm{~m} \times 0,5 \mathrm{~m}$ (M. sacchariflorus). Zabiegi uprawowe i pielęgnacyjne prowadzono zgodnie $\mathrm{z}$ ogólnie przyjętymi zaleceniami agrotechnicznymi.

Badania nad występowaniem chorób na nadziemnych częściach roślin przeprowadzono w lipcu i wrześniu, w latach 2012-2013. U wszystkich badanych gatunków oceniano porażenie liści, a u $H$. tuberosus, S. hermaphrodita i $S$. perfoliatum dodatkowo pędów. W nasadzeniu każdego gatunku oceniano nasilenie występowania chorób, analizując zdrowotność 25 losowo wybranych roślin, po przekątnej każdego poletka. Porażenie liści przez grzyby chorobotwórcze określano według skali 5-stopniowej, a pędów 3-stopniowej. Uzyskane wyniki przedstawiono w postaci indeksu porażenia (Ip) (Burgieł 1984). W oparciu o obliczony w latach badań średni stopień porażenia utworzono trzy grupy porażenia dla liści: porażenie słabe $(0,1-2,0)$, średnie $(2,1-4,0)$ i silne $(4,1-5,0)$ oraz dla pędów: słabe $(0,1-1,0)$, średnie $(1,1-2,0)$ i silne $(2,1-3,0)$. Identyfikacji sprawców chorób dokonywano w oparciu o klucze (Gilman 1957; Ellis 1971; Arx 1974; Barnett i Hunter 1999) oglądając pod mikroskopem wodne preparaty zarodników inkubowanych w wilgotnych komorach i na sztucznych pożywkach.

W latach 2012-2013 wegetacja roślin energetycznych przebiegała w podobnych warunkach pogodowych (tab. 1). Lata 2012 i 2013 były ciepłe i suche. W szczególności dotyczyło to miesięcy: lipiec, sierpień i wrzesień, w których sumy opadów były wyraźnie mniejsze, a średnie temperatury powietrza były zbliżone do średnich $\mathrm{z}$ wielolecia. $\mathrm{W}$ obu latach badań, wymienione miesiące poprzedzał bardzo mokry i ciepły czerwiec, w którym opady znacznie przekroczyły średnią dla wielolecia.

Tabela 1. Warunki pogodowe w latach 2012-2013 (dane Stacji Meteorologicznej Uniwersytetu Rzeszowskiego)

Table 1. Weather conditions during 2012-2013 (data from Meteorological Station of the University of Rzeszów)

\begin{tabular}{|c|c|c|c|c|c|c|}
\hline \multirow{2}{*}{$\begin{array}{l}\text { Miesiąc } \\
\text { Month }\end{array}$} & \multicolumn{3}{|c|}{$\begin{array}{c}\text { Temperatura - Temperature } \\
{\left[{ }^{\circ} \mathrm{C}\right]}\end{array}$} & \multicolumn{3}{|c|}{$\begin{array}{l}\text { Opady - Rainfall } \\
{[\mathrm{mm}]}\end{array}$} \\
\hline & 2012 & 2013 & $\begin{array}{c}\text { średnio za lata } \\
\text { mean for years } \\
\text { 1986-2012 }\end{array}$ & 2012 & 2013 & $\begin{array}{c}\text { średnio za lata } \\
\text { mean for years } \\
\text { 1986-2012 }\end{array}$ \\
\hline $\mathrm{V}$ & 14,6 & 15,1 & 13,8 & 64,6 & 67,3 & 82,6 \\
\hline VI & 18,1 & 18,4 & 17,1 & 102,5 & 141,1 & 84,6 \\
\hline VII & 20,8 & 18,8 & 19,1 & 46,9 & 59,1 & 96,2 \\
\hline VIII & 18,8 & 18,8 & 18,3 & 20,3 & 10,9 & 66,6 \\
\hline IX & 14,9 & 12,0 & 13,3 & 8,9 & 56,2 & 66,6 \\
\hline $\begin{array}{c}\text { Średnia/Suma } \\
\text { Mean/Total } \\
\text { (V-IX) }\end{array}$ & 17,4 & 16,6 & 16,3 & 243,2 & 334,6 & 396,6 \\
\hline
\end{tabular}




\section{Wyniki i dyskusja / Results and discussion}

W każdym roku obserwacji, na roślinach energetycznych wystąpiły następujące choroby: mączniak prawdziwy (H. tuberosus - liście i pędy), szara pleśń (H. tuberosus, S. perfoliatum - liście), plamistość liści (M. giganteus, M. sacchariflorus, S. hermaphrodita liście) i zgnilizna twardzikowa (S. hermaphrodita - pędy) (tab. 2, 3).

W zależności od porażonego organu, nasilenie wymienionych chorób było zróżnicowane. Dominującą chorobą na liściach roślin energetycznych (średnio 60\% porażonych roślin) był mączniak prawdziwy (Erysiphe cichoreacerum) występujący na $H$. tuberosus (tab. 2). W naszych warunkach klimatycznych jest on chorobą bardzo groźną, stanowiącą poważne zagrożenie dla upraw tego gatunku (Remlein-Starosta 2008a). Występowanie mączniaka prawdziwego na tej roślinie notowano również w innych strefach klimatycznych (McCarter i Kays 1984; McCarter 1993; Cho i wsp. 2012). W obu latach prowadzonych badań pierwsze objawy mączystego nalotu notowano w lipcu. Intensywny rozwój E. cichoreacerum obserwowano w każdym sezonie wegetacyjnym, zwykle w sierpniu, po upalnej i suchej pogodzie w lipcu. Wynikało to $\mathrm{z}$ nagromadzenia się czynnika infekcyjnego - zarodników konidialnych, które mają zdolność szybkiego wytwarzania się w warunkach jakie notowano w lipcu. Wcześniej o tej zależności donosili Kays i Nottingham (2007) informując, że bardzo duży wpływ na rozwój sprawcy mączniaka prawdziwego na roślinach $H$. tube- rosus ma temperatura $\mathrm{w}$ zakresie $18-24^{\circ} \mathrm{C}$. Największe średnie porażenie (śr. Ip $=41,9 \%$ ) wystąpiło w 2013 roku i było ono wyższe o 7,3\% niż w 2012 roku. W okresie badań choroba wystąpiła średnio na $60 \%$ roślin, w tym najwięcej roślin charakteryzowało się średnim porażeniem. Oprócz liści, E. cichoreacerum opanowywał również łodygi $H$. tuberosus. Podczas dwuletnich badań jej rozwój był słabszy (śr. Ip $=16,5 \%$ ), występując średnio na $44 \%$ roślin (tab. 3). O dużym, co roku rozpowszechnianiu się mączniaka prawdziwego (E. cichoreacerum) w Winnej Górze i silnym porażeniu roślin topinamburu donosiła Remlein-Starosta (2007), wskazując na poważny problem jaki stanowi szkodliwość tej choroby.

Poważnym problemem w latach badań dla S. hermaphrodita była plamistość liści (Phoma sp.). Nasilenie tej choroby (śr. Ip $=30,6 \%$ ) było jednak słabsze od porażenia przez E. cichoreacerum topinamburu (tab. 3). Występowanie plamistości liści stwierdzono średnio na $48 \%$ roślin S. hermaphrodita, a najwyższe nasilenie (śr. Ip $=36,2 \%$ ) odnotowano w 2013 roku. Ponadto na pędach S. hermaphrodita odnotowywano zgniliznę twardzikową (Sclerotinia sclerotiorum). W tym przypadku, była to choroba dominująca na pędach (tab. 3). Obecnie jest to nagroźniejsza choroba występująca na roślinach $S$. hermaphrodita, zagrażająca jej uprawom (Remlein-Starosta 2008b). Uzyskane wyniki wykazały, że w rejonie Rzeszowa choroba opanowywała prawie dwukrotnie więcej pędów (średnio 52\%) w porównaniu do wyników badań $(30 \%$ porażonych pędów) prowadzonych przez Remlein-Starostę (2008a, b).

Tabela 2. Nasilenie chorób liści roślin energetycznych

Table 2. Severity of leaf diseases of energy crops

\begin{tabular}{|c|c|c|c|c|c|c|c|}
\hline \multirow{4}{*}{ Gatunek - Species } & \multirow{4}{*}{$\begin{array}{l}\text { Choroba/Patogen } \\
\text { Disease/Pathogen }\end{array}$} & \multirow{3}{*}{\multicolumn{3}{|c|}{$\begin{array}{c}\text { Udział porażonych roślin } \\
\text { w latach 2012-2013 } \\
\text { Share of infected plants } \\
\text { in 2012-2013 } \\
\text { [\%] } \\
\text { porażenie - infection }\end{array}$}} & \multicolumn{3}{|c|}{$\begin{array}{l}\text { Indeks porażenia } \\
\text { Infection index } \\
\text { (Ip) [\%] }\end{array}$} \\
\hline & & & & & \multicolumn{2}{|c|}{ rok - year } & \multirow{3}{*}{$\begin{array}{l}\text { średnio } \\
\text { mean }\end{array}$} \\
\hline & & & & & \multirow[b]{2}{*}{2012} & \multirow[b]{2}{*}{2013} & \\
\hline & & $\begin{array}{l}\text { słabe } \\
\text { weak }\end{array}$ & $\begin{array}{l}\text { średnie } \\
\text { medium }\end{array}$ & $\begin{array}{l}\text { silne } \\
\text { severe }\end{array}$ & & & \\
\hline $\begin{array}{l}\text { Miskant cukrowy } \\
\text { Miscanthus sacchariflorus }\end{array}$ & $\begin{array}{l}\text { plamistości liści: } \\
\text { leaf spot diseases: } \\
\text { Alternaria alternata, } \\
\text { Helminthosporium spp., } \\
\text { Stagonospora tainaenensis }\end{array}$ & 8 & 0 & 0 & 1,1 & 0,5 & 0,8 \\
\hline $\begin{array}{l}\text { Miskant olbrzymi } \\
\text { Miscanthus giganteus }\end{array}$ & $\begin{array}{l}\text { plamistości liści: } \\
\text { leaf spot diseases: } \\
\text { Alternaria alternata, } \\
\text { Helminthosporium spp., } \\
\text { Stagonospora tainaenensis }\end{array}$ & 8 & 4 & 4 & 0,5 & 0,3 & 0,4 \\
\hline \multirow{2}{*}{$\begin{array}{l}\text { Słonecznik bulwiasty } \\
\text { (topinambur) } \\
\text { Helianthus tuberosus }\end{array}$} & $\begin{array}{l}\text { mączniak prawdziwy } \\
\text { Erysiphe cichoreacerum }\end{array}$ & 12 & 20 & 28 & 34,6 & 41,9 & 38,2 \\
\hline & $\begin{array}{l}\text { szara pleśń } \\
\text { Botrytis cinerea }\end{array}$ & 32 & 28 & 8 & 19,6 & 28,3 & 23,9 \\
\hline $\begin{array}{l}\text { Sylfia przerośnięta } \\
\text { Sylphium perfoliatum }\end{array}$ & $\begin{array}{l}\text { Szara pleśń } \\
\text { Botrytis cinerea }\end{array}$ & 20 & 8 & 4 & 18,6 & 24,8 & 21,7 \\
\hline $\begin{array}{l}\text { Ślazowiec pensylwański } \\
\text { Sida hermaphrodita }\end{array}$ & $\begin{array}{l}\text { plamistość liści } \\
\text { leaf spot diseases } \\
\text { Phoma sp. }\end{array}$ & 28 & 16 & 4 & 24,9 & 36,2 & 30,6 \\
\hline
\end{tabular}


Tabela 3. Nasilenie chorób pędów roślin energetycznych

Table 3. Severity of diseases of shoots of energy crops

\begin{tabular}{|c|c|c|c|c|c|c|c|}
\hline \multirow{4}{*}{ Gatunek - Species } & \multirow{4}{*}{$\begin{array}{l}\text { Choroba/Patogen } \\
\text { Disease/Pathogen }\end{array}$} & \multirow{3}{*}{\multicolumn{3}{|c|}{$\begin{array}{l}\text { Udział porażonych roślin } \\
\text { w latach 2012-2013 } \\
\text { Share of infected plants } \\
\text { in 2012-2013 } \\
\text { [\%] } \\
\text { porażenie - infection }\end{array}$}} & \multicolumn{3}{|c|}{$\begin{array}{l}\text { Indeks porażenia } \\
\text { Infection index } \\
\text { (Ip) [\%] }\end{array}$} \\
\hline & & & & & \multicolumn{2}{|c|}{ rok - year } & \multirow{3}{*}{$\begin{array}{c}\text { średnio } \\
\text { mean }\end{array}$} \\
\hline & & & & & \multirow[b]{2}{*}{2012} & \multirow[b]{2}{*}{2013} & \\
\hline & & $\begin{array}{l}\text { słabe } \\
\text { weak }\end{array}$ & $\begin{array}{l}\text { średnie } \\
\text { medium }\end{array}$ & $\begin{array}{l}\text { silne } \\
\text { severe }\end{array}$ & & & \\
\hline $\begin{array}{l}\text { Słonecznik bulwiasty } \\
\text { (topinambur) } \\
\text { Helianthus tuberosus }\end{array}$ & $\begin{array}{l}\text { mączniak prawdziwy } \\
\text { Erysiphe cichoreacerum }\end{array}$ & 16 & 12 & 4 & 13,4 & 19,7 & 16,5 \\
\hline $\begin{array}{l}\text { Sylfia przerośnięta } \\
\text { Sylphium perfoliatum }\end{array}$ & $\begin{array}{l}\text { szara pleśń } \\
\text { Botrytis cinerea }\end{array}$ & 12 & 12 & 4 & 5,6 & 14,8 & 10,2 \\
\hline $\begin{array}{l}\text { Ślazowiec pensylwański } \\
\text { Sida hermaphrodita }\end{array}$ & \begin{tabular}{|l|} 
zgnilizna twardzikowa \\
Sclerotinia sclerotiorum
\end{tabular} & 28 & 16 & 8 & 18,8 & 22,7 & 20,7 \\
\hline
\end{tabular}

Z przeprowadzonej analizy zdrowotności badanych gatunków roślin energetycznych wynika, że zagrożeniem dla $H$. tuberosus i $S$. perfoliatum była również szara pleśń (Botrytis cinerea). Zdecydowanie najsilniejszy rozwój szarej pleśni na liściach i pędach roślin obserwowano w 2013 roku. Najwyższe średnie porażenie przez B. cinerea odnotowano na liściach $H$. tuberosus (śr. Ip $=23,9 \%$ ) i $S$. perfoliatum (śr. Ip $=21,7 \%$ ), a słabsze na pędach S. perfoliatum (śr. Ip = 10,2\%) (tab. 3).

Wśród roślin rosnących na kolekcji, najsłabsze porażenie czynnikiem infekcyjnym stwierdzono na miskatach. Analiza średnich indeksów porażenia wykazała, że plamistość liści opanowywała te rośliny w niewielkim stopniu (tab. 2). Najniższy indeks porażenia (śr. Ip =0,4\%) zanotowano na roślinach $M$. giganteus i był on dwukrotnie niższy niż na $M$. sacchariflorus. Sprawcami wymienionej choroby były wyosobnione $\mathrm{z}$ chorych fragmentów liści grzyby, takie jak: Helminthosporium spp., Stagonospora tainaenensis oraz dominujący gatunek Alternaria alternata. Wymienione patogeny w ocenie wielu autorów stanowią potencjalne niebezpieczeństwo dla upraw miskanta w Polsce (Remlein-Starosta 2008a; Kotecki 2010; Pusz i Pląskowska 2010). Uzyskane wyniki znajdują potwierdzenie w badaniach innych autorów, którzy wskazują na wzrost zagrożenia upraw roślin energetycznych przez choroby.

Każda kolekcja roślin powinna posiadać walory dekoracyjne i stanowić istotny element na obszarach krajobrazu otwartego, dlatego wymaga ona stałej ochrony roślin. Kolekcja roślin energetycznych (H. tuberosus, S. hermaphrodita, S. perfoliatum, M. giganteus, M. sacchariflorus) zlokalizowana na polu doświadczalnym w Krasnem koło Rzeszowa stanowi bogaty i cenny materiał do badań naukowych dla studentów i pracow- ników. Wyeksponowane tu rośliny pokazowe, służące do celów dydaktycznych i naukowych, powinny charakteryzować się dobrą zdrowotnością. Choroby występujące na liściach i pędach roślin energetycznych mogą bowiem przyczynić się do ich przedwczesnego zamierania i defoliacji liści, czego skutkiem będzie spadek przyrostu pędów i obniżenie plonu masy. W świetle przedstawionych informacji zasadne wydaje się wprowadzenie zabiegów ochrony roślin, gdyż ograniczą one skutki, które wynikają z powstania warunków sprzyjających infekcji i rozwojowi czynników chorobotwórczych. Niechronione rośliny na kolekcji tracą swój estetyczny wygląd i są co roku źródłem infekcji, z których patogeny rozprzestrzeniają się na nowe rośliny, również na sąsiadujące z kolekcją pola uprawne.

\section{Wnioski / Conclusions}

1. Plamistość liści wystąpiła na roślinach M. sacchariflorus i M. giganteus (A. alternata, Helminthosporium spp., S. tainaenensis) oraz S. hermaphrodita (Phoma sp.), szara pleśń (B. cinerea) na $H$. tuberosus i $S$. perfoliatum, mączniak prawdziwy (E. cichoreacerum) na $H$. tuberosus, a zgnilizna twardzikowa (S. sclerotiorum) na $S$. hermaphrodita.

2. Intensywność nasilenia chorób zależała od warunków pogodowych i gatunku rośliny. Chorobami o największym nasileniu były: mączniak prawdziwy (H. tuberosus - liście), plamistość liści (S. hermaphrodita liście) i zgnilizna twardzikowa (S. hermaphrodita liście). W warunkach Podkarpacia, choroby te moga stwarzać największe zagrożenie dla plantacji roślin energetycznych.

\section{Literatura / References}

Arx J.A. 1974. The Genera of Fungi. J. Cramer, Vaduz, 424 pp.

Barnett H.L., Hunter B.B. 1999. Illustrated Genera of Imperfect Fungi. APS Press, St. Paul, Minnesota, 218 pp.

Burgieł Z. 1984. Wpływ niektórych herbicydów na występowanie i rozwój patogenów powodujących choroby podsuszkowe pszenicy ozimej. Cz. II. Rozwój patogenów. Acta Agraria et Silvestria, Seria Agraria 23: 187-196. 
Cho S.-E., Park M.-J., Park J.-H., Han K.-S., Shin H.-D. 2012. First report of Golovinomyces cichoracearum associated with powdery mildew on Helianthus tuberosus in Korea. Australasian Plant Disease Notes 7 (1): 35-37.

Ellis M.B. 1971. Dematiaceous, Hyphomycetetes. DMI, Kew, Surrey, England, 608 pp.

Gilman J.C. 1957. A Manual of Soil Fungi. ISCP, Iowa, USA, 450 pp.

Kays J.S., Nottingham F.N. 2007. Biology and chemistry of Jerusalem artichoke. CRC Press, New York, USA: 375-376.

Kotecki A. (red.). 2010. Uprawa miskanta olbrzymiego. Wydawnictwo Uniwersytetu Przyrodniczego we Wrocławiu: $138-146$.

McCarter S.M. 1993. Reactions of Jerusalem artichoke genotypes to two rusts and powdery mildew. Plant Disease 77 (3): $242-245$.

McCarter S.M., Kays S.J. 1984. Diseases limiting of Jerusalem artichokes in Georgia. Plant Disease 68 (4): $299-302$.

Pusz W., Pląskowska E. 2010. Stagonospora tainanensis - new patogen of giant miscanthus (Miscanthus $\times$ giganteus Greef et Deu) in Poland. Phytopathologia 57: 39-43.

Remlein-Starosta D. 2007. Choroby roślin energetycznych. [Diseases of bioenergy crops]. Progress in Plant Protection/Postępy w Ochronie Roślin 47 (4): 351-357.

Remlein-Starosta D. 2008a. Szkodliwość najważniejszych patogenów wybranych roślin energetycznych. Pamiętnik Puławski 148: 79-85.

Remlein-Starosta D. 2008b. Szkodliwość zgnilizny twardzikowej na ślazowcu pensylwańskim i możliwości jej ograniczania. [Damages cause by Sclerotinia rot on Virginia mallow and possibility of it control]. Progress in Plant Protection/Postępy w Ochronie Roślin 48 (3): 1106-1110. 